\title{
Development Assistance of Integrated Science Instructional Material by Integrating Real World Context and Scientific Literacy on Science Teachers
}

\author{
Asrizal $^{\# 1}$, Wahyuni Satria Dewi ${ }^{\# 1}$, \\ 1 Jurusan Fisika, FMIPA, Universitas Negeri Padang \\ Jln. Prof. Dr. Hamka Air Tawar Padang, Sumatera Barat, Indonesia

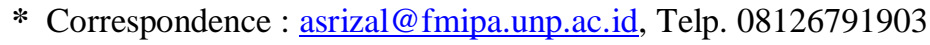

Diterima 19 November 2018, Disetujui 23 November 2018, Dipublikasikan 30 November 2018

\begin{abstract}
Science teaching in junior high schools should be conducted in integrated form. However, the real condition shows that in implementing the integrated science teaching in the schools was found problem. The solution of this problem is to develop integrated science teaching materials by integrating real-world context and scientific literacy on Science teachers in East Agam district. The objective of the activity is to assist science teachers in developing integrated science teaching material and apply it in science teaching in the classroom. Participants of program assistance were 40 science teachers who were members of the Science MGMP in East Agam district. The instrument for collecting data consisted of pretest and posttest, performance assessment sheet, and questionnaire sheet. The data were analyzed by descriptive statistics analysis and correlated comparison test. Based on the results of data analysis can be stated that: 1). The validity of the integrated science instructional materials in the assistance program can be entered into the good category, 2). The practicality average value of using integrated science instructional material according to students can be grouped into very good category, 3).The average value of the science teacher's response to the implementation of program assistance for the development of integrated science teaching material can be classified into very good category, and 4). The implementation of the program assistance for the development of integrated science teaching material is effective to improve the understanding of science teachers on the material of instructional material, the concept of integrated science teaching, and the concept of scientific literacy.
\end{abstract}

Keywords - Instructional material, Integrated science, Real world context, Scientific literacy

\section{Pendahuluan}

Kementrian Pendidikan dan Kebudayaan RI menuntut bahwa pembelajaran IPA di SMP seharusnya dilaksanakan secara terpadu. Dalam pendekatan konten kurikulum tahun 2013, kompetensi siswa di SMP dikembangkan melalui mata pelajaran terpadu dan tematik. Di sisi lain, dalam elemen proses pembelajaran, IPA diajar kan dalam bentuk pembelajaran terpadu. Isi pembelajaran di SMP didasarkan pada konsep terpadu dari berbagai disiplin ilmu untuk tujuan pendidikan dari mata pelajaran IPA. Konsep terpadu dalam IPA ini ditunjukkan pada kompetensi inti dan kompetensi dasar. Dalam kompetensi dasar telah memadukan konsep- konsep IPA dari sub disiplin dari Biologi, Fisika, Kimia, serta Ilmu Bumi dan Antariksa.

Pembelajaran IPA terpadu mendukung kerang ka pengembangan kurikulum IPA yang mengait kan IPA dengan kehidupan sehari-hari, lingkung an, dan teknologi. Dalam pembelajaran terpadu, siswa dilatih mengembangkan literasi dalam mengkonstruksi kompetensi secara aktif, autentik, bermakna, dan holistik. Pembelajaran ini relevan dengan salah satu prinsip esensial dari pembelajar an abad ke-21, yaitu pembelajaran seharusnya mempunyai konteks [1]. Artinya materi pembe lajaran IPA perlu dikaitkan dengan situasi dunia nyata. Dengan cara ini, pembelajaran IPA terpadu mendukung kerangka pengembangan kurikulum IPA di SMP/MTs.

Kementrian Pendidikan dan Kebudayaan RI juga mendorong pengembangan literasi siswa 
melalui program gerakan literasi sekolah yang dikenal dengan GLS. Literasi merupakan keteram pilan penting yang harus dimiliki oleh setiap siswa agar mereka sukses dalam belajar dan kehidupan sehari-hari. GLS bertujuan untuk men ciptakan lingkungan sekolah menjadi lingkungan pembelajar sepanjang hayat dengan membudaya kan aktivitas membaca, menyimak, menulis, dan berbicara yang baik. Keterampilan-keterampilan tersebut sangat diperlukan dalam menciptakan pembelajaran yang kreatif dan produktif.

Literasi saintifik merupakan arena penting untuk membantu siswa dalam menyikapi dan mengambil keputusan yang berhubungan dengan permasalahan IPA dalam kehidupannya. Literasi saintifik adalah penting karena suatu pemahaman dari IPA menyediakan pemenuhan dan kegembira an pribadi siswa. Heller menyatakan empat alasan bahwa literasi saintifik penting dalam kehidupan. Pertama, daya saing dan kemampuan kerja terkait erat dengan kapasitas individu untuk berparti sipasi secara aktif dan mempromosikan inovasi. Kedua, dalam abad ke-21 IPA dan teknologi telah memainkan peran penting dalam banyak bidang di masyarakat. Ketiga, banyak masalah sosial terbesar saat ini melibatkan komponen ilmiah dan teknologi yang penting. Terakhir, dunia membu tuhkan warga negara dengan keterampilan ber pikir kritis [2].

Meskipun kementrian pendidikan dan kebudayaan telah menuntut penerapan pembelajar an IPA terpadu dan integrasi literasi dalam pembelajaran, namun kondisi nyata di sekolah belum sesuai dengan kondisi yang diharapkan. Kondisi nyata ini juga ditemukan pada mitra MGMP IPA SMP kabupaten Agam. Berdasarkan studi pendahuluan yang telah dilakukan pada mitra MGMP IPA SMP kabupaten Agam diketahui kondisi nyata yang dihadapi oleh mitra PKM. Ada tiga kegiatan studi pendahuluan yang telah dilakukan pada mitra, yaitu pemberian angket tentang penerapan pembelajaran IPA terpadu, observasi dalam kegiatan MGMP IPA SMP Kabupaten Agam, dan wawancara tentang integrasi literasi dalam pembelajaran.

Kondisi nyata pertama berkenaan dengan penerapan pembelajaran IPA terpadu di Sekolah. Instrumen yang digunakan untuk mengetahui kondisi nyata ini adalah angket. Angket diberikan kepada 32 orang guru anggota MGMP IPA SMP kabupaten Agam. Dari hasil analisis angket dapat dinyatakan bahwa: 1). guru belum memiliki kesiapan yang baik untuk menerapkan pembelajar an IPA terpadu, 2). guru belum memiliki keyakin an yang bagus untuk menyusun perangkat pembe lajaran IPA terpadu, 3). sebagian besar guru mengalami kesulitan dalam menerapkan pembe lajaran IPA terpadu, dan 4). kegiatan pengem bangan diri guru yang berhubungan dengan pembelajaran IPA terpadu masih kurang. Hasil analisis angket ini mengindikasikan bahwa pembelajaran IPA terpadu belum dapat diterap kan dengan baik disebabkan oleh kendala-ken dala yang dihadapi oleh anggota mitra [3].

Kondisi nyata kedua berhubungan dengan penulisan bahan ajar IPA. Kondisi ini diketahui dari observasi yang dilakukan pada kegiatan pelatihan penulisan bahan ajar pada guru MGMP IPA SMP kabupaten Agam. Dari hasil observasi dapat digambarkan bahwa guru-guru anggota mitra MGMP IPA SMP kabupaten Agam masih mengalami kesulitan dalam menuliskan gagasan untuk menghasilkan baik bahan ajar maupun karya ilmiah. Pada kegiatan bimbingan ini dike tahui bahwa banyak anggota mitra yang meng alami kesulitan dalam menulis proposal peneliti an dan bahan ajar. Kondisi ini mengindikasikan bahwa keterampilan menulis dari anggota mitra masih rendah.

Kondisi nyata terakhir berkaitan dengan integrasi literasi dalam pembelajaran IPA di Sekolah. Kondisi ini didapatkan dari hasil wawancara dengan ketua MGMP IPA SMP kabupaten Agam. Dari hasil wawancara diketahui bahwa guru-guru IPA telah menyadari bahwa literasi adalah penting bagi siswa untuk berhasil baik dalam belajar maupun dalam kehidupan sehari-hari mereka, namun mereka masih kesulit an dalam menerapkan keterampilan literasi dalam pembelajaran. Disamping itu, literasi yang diterap kan di sekolah baru literasi membaca, padahal masih banyak lagi keterampilan literasi yang dapat diterapkan untuk mendukung keberhasilan siswa baik dalam belajar maupun dalam kehidup an mereka sehari-hari. Hasil wawancara mengindi kasikan bahwa guru-guru MPMP IPA kabupaten Agam masih mengalami kesulitan dalam meng integrasikan literasi ke dalam pembelajaran. 
Berdasarkan studi pendahuluan yang telah dilakukan pada mitra MGMP IPA SMP Kabu paten Agam dapat diketahui permasalahan yang dihadapi oleh mitra PKM. Ada tiga permasalahan utama yang dihadapi oleh guru anggota mitra dalam menerapkan pembelajaran IPA terpadu dan mengintegrasikan literasi dalam pembelajaran. Permasalahan pertama adalah guru-guru anggota mitra mengalami kesulitan dalam menerapkan pembelajaran IPA terpadu di sekolah. Salah satu penyebab utamanya adalah tidak tersedianya bahan ajar IPA terpadu yang dapat digunakan untuk mendukung pembelajaran IPA terpadu. Permasalahan kedua adalah guru-guru anggota mitra masih mengalami kesulitan dalam menulis bahan ajar IPA terpadu. Permasalahan ini disebab kan oleh kurangnya keterampilan menulis karya ilmiah seperti bahan ajar. Permasalahan ketiga adalah guru-guru anggota mitra mengalami kesu litan mengintegrasikan literasi dalam pem bela jaran untuk meningkatkan keterampilan literasi siswa. Permasalahan ini disebabkan oleh kurang nya pelatihan dan bimbingan yang dapat diikuti oleh guru untuk meningkatkan literasi siswa.

\section{Solusi/Teknologi}

Upaya untuk mengatasi permasalahan dan kendala guru dalam menerapkan pembelajaran IPA terpadu dan mengintegrasikan literasi dalam pembelajaran IPA perlu dilakukan. Salah satu alternatif solusi yang dapat ditawarkan untuk memecahkan permasalahan mitra adalah "Prog ram Pendampingan Pengembangan Bahan Ajar IPA Terpadu Bermuatan Konteks Dunia Nyata dan Literasi Saintifik". Solusi ini diperkirakan sesuai dengan kebijakan kementrian Pendidikan dan Kebudayaan Republik Indonesia dan permasa lahan dari mitra.

Landasan teori pertama yang berhubungan dengan solusi adalah bahan ajar. Bahan ajar diperlukan untuk menciptakan proses pembelajar an yang efektif. Bahan ajar merupakan seperang kat materi atau substansi pelajaran yang disusun secara sistematis, menampilkan sosok utuh dari kompetensi yang akan dikuasai oleh siswa dalam kegiatan pembelajaran [4]. Pengertian lain dari bahan ajar segala sesuatu yang digunakan oleh guru untuk mendukung, memfasilitasi, mempe ngaruhi atau memperoleh pengetahuan, kompe tensi dan keterampilan [5]. Dengan bahan ajar, guru dapat mendorong dan memfasilitasi siswa untuk belajar.

Bahan ajar memiliki fungsi strategis dalam proses pembelajaran. Bahan ajar dapat membantu guru dan siswa dalam kegiatan pembelajaran sehingga guru tidak terlalu banyak menyajikan materi [6]. Bahan ajar memberikan peran baik bagi guru maupun siswa dalam pembelajaran. Peran bahan ajar bagi guru adalah: menghemat waktu dalam pembelajaran, mengubah peran guru menjadi fasilitator, dan meningkatkan proses pembelajaran menjadi lebih efektif dan interaktif. Disisi lain, peran bahan ajar bagi siswa antara lain: mengurangi ketergantungan pada guru dalam belajar, dapat belajar tanpa harus dibatasi oleh waktu dan tempat, dapat belajar sesuai dengan kecepatan sendiri, dapat belajar menurut urutan yang dipilih, dan membantu potensi untuk menjadi pembelajaran mandiri.

Dalam pembelajaran bahan ajar mempunyai tiga fungsi. Pertama, pedoman bagi guru untuk mengarahkan semua aktivitasnya dalam proses pembelajaran, sekaligus merupakan subtansi kom petensi yang seharusnya diajarkan kepada siswa. Kedua, pedoman bagi siswa yang akan mengarah kan semua aktivitasnya dalam proses pembe lajaran, sekaligus merupakan subtansi kompetensi yang harus dikuasainya. Ketiga, sebagai alat evaluasi pencapaian hasil pembelajaran [7]. Dengan demikian, keberadaan bahan ajar adalah penting dalam proses pembelajaran.

Landasan teori kedua yang berhubungan dengan solusi adalah pembelajaran terpadu. Pembelajaran terpadu merupakan suatu sistem pembelajaran yang memungkinkan siswa baik secara individual maupun kelompok aktif mencari, menggali dan menemukan konsep serta prinsip keilmuwan secara holistik, bermakna dan autentik [8]. Pengertian lain dari pembelajaran terpadu adalah pembelajaran yang dalam pemba hasan materinya meliputi atau saling mengaitkan berbagai bidang studi atau mata pelajaran secara terpadu dalam suatu fokus tertentu [9]. Dari kedua kutipan dapat dikemukakan bahwa pembe lajaran terpadu merupakan pembelajaran yang mengaitkan antara suatu disiplin ilmu dengan disiplin ilmu lainnya untuk membuat pembelajar an bermakna dan holistik. 
Secara umum pelaksanaan pembelajaran IPA terpadu memiliki tiga tujuan. Tujuan pertama adalah meningkatkan efisiensi dan efektivitas pembelajaran. Bila konsep yang tumpang tindih dan pengulangan dapat dipadukan, maka pembe lajaran akan lebih efisien dan efektif. Tujuan kedua adalah meningkatkan minat dan motivasi. Pembelajaran IPA terpadu dapat mempermudah dan memotivasi peserta didik untuk mengenal, menerima, menyerap, dan memahami keterkaitan atau hubungan antara konsep pengetahuan dan nilai atau tindakan yang termuat dalam tema tersebut. Tujuan ketiga adalah mencapai beberapa kompetensi dasar sekaligus [10]. Pembelajaran terpadu dapat menyederhanakan langkah pembe lajaran dengan adanya proses penyatuan sejumlah kompetensi dasar yang dipandang memiliki keter kaitan antara satu dengan yang lainnya.

Pembelajaran terpadu di tingkat SMP memegang peranan penting dalam pembentukan kompetensi siswa. Ada beberapa alasan yang mendasari pentingnya pembelajaran terpadu. Pertama, dunia anak adalah dunia nyata. Tingkat perkembangan mental anak selalui dimulai dengan tahap berpikir nyata. Kedua, proses pemahaman anak terhadap suatu konsep dalam suatu objek atau peristiwa lebih terorganisir. Ketiga, pembelajaran akan lebih bermakna. Pembelajaran lebih bermakna kalau pelajaran yang sudah dipelajari siswa dapat dimanfaatkan nya untuk mempelajari materi berikutnya. Pembe lajaran terpadu sangat berpeluang untuk meman faatkan pengetahuan sebelumnya. Keempat, mem beri peluang siswa untuk mengembangkan kemampuan diri. Pembelajaran terpadu memberi peluang siswa untuk mengembangkan tiga ranah sasaran pendidikan secara bersamaan. Kelima, memperkuat kemampuan yang diperoleh. Kemam puan yang diperoleh dari satu mata pelajaran akan saling memperkuat kemampuan yang diperoleh dari mata pelajaran lain. Terakhir, efisien waktu pembelajaran. Dalam pembelajaran terpadu guru dapat lebih menghemat waktu dalam menyusun rencana pembelajaran [11].

Sebagai suatu proses, pembelajaran terpadu memiliki karakteristik tertentu. Ada beberapa karakteristik pembelajaran terpadu yaitu: berpusat pada siswa, memberikan pengalaman langsung kepada siswa, pemisahan antar bidang studi tidak begitu jelas, menyajikan konsep dari berbagai bidang studi dalam suatu proses pembelajaran, bersifat luwes, dan hasil pembelajaran dapat berkembang sesuai dengan minat dan kebutuhan siswa [12]. Disisi lain, Triyanto [13] menyatakan bahwa "pembelajaran terpadu sebagai suatu pro ses mempunyai beberapa karakteristik atau ciriciri yaitu: holistik, bermakna, autentik, dan aktif'.

Landasan teori ketiga yang berkaitan dengan solusi adalah pembelajaran kontekstual. Pembelajaran yang dilakukan seharusnya memi liki konteks atau suasana. Artinya materi pembe lajaran perlu dikaitkan dengan kehidupan seharihari siswa. Pembelajaran kontekstual adalah suatu konsep yang membantu guru menghubungkan materi pembelajaran pada situasi dunia nyata sebagai anggota keluarga, sebagai warga negara, dan sebagai pekerja [14]. Pengertian lain dari pembelajaran kontekstual adalah suatu konsepsi dari pembelajaran yang membantu guru menghu bungkan konten materi pembelajaran pada situasi dunia nyata dan memotivasi siswa untuk mem buat hubungan antara pengetahuan dan aplikasi nya dalam kehidupan sehari-hari [15]. Berarti pembelajaran kontektual dapat mendorong siswa untuk menghubungkan materi pembelajaran dengan kehidupan sehari-hari sekitar siswa, ling kungan, teknologi, dan kesehatan.

Pembelajaran kontekstual bertujuan untuk membantu peserta didik memahami materi pelajaran yang sedang mereka pelajari dengan menghubungkan pokok materi pelajaran dengan penerapannya dalam kehidupan sehari-hari. Pem belajaran kontekstual memotivasi peserta didik untuk bertanggung jawab dari belajar mereka dan untuk membuat hubungan antara pengetahuan dengan aplikasinya pada berbagai konteks dari kehidupan mereka. Pembelajaran ini menyedia kan suatu kerangka konseptual untuk menyatukan sekumpulan teori-teori dan praktek-praktek pendi dikan, serta menunjukkan suatu pendekatan untuk meningkatkan pendidikan [14].

Landasan teori terakhir yang terkait dengan solusi adalah literasi saintifik (scientific literacy). Literasi saintifik sering dihubungkan dengan kemampuan dalam pengetahuan ilmiah seperti IPA. Literasi saintifik didefinisikan sebagai suatu pengetahuan ilmiah individu dan menggunakan pengetahuan tersebut untuk mengidentifikasi per 
tanyaan, untuk memperoleh pengetahuan baru, untuk menjelaskan fenomena ilmiah, dan untuk melukiskan kesimpulan didasarkan pada bukti [16]. Pengertian lain literasi saintifik adalah pengetahuan dan penguasaan dari konsep dan proses saintifik yang diperlukan untuk meng ambil keputusan personal, partisipasi dalam urusan kewarganegaraan dan budaya, dan produk tivitas ekonomi [17]. Literasi saintifik menghu bungkan pada kemampuan untuk berpikir secara ilmiah dan menggunakan pengetahuan dan proses ilmiah untuk memahami dunia sekitar kita dan untuk berpartisipasi dalam keputusan yang mempengaruhinya.

Literasi saintifik memiliki tiga dimensi. Pertama konsep saintifik yaitu literasi yang dibutuhkan untuk menguasai fenomena tertentu dari dunia alam dan perubahan yang terjadi di alam melalui kegiatan manusia. Kedua proses saintifik yang dipusatkan pada kemampuan untuk memperoleh, menginterpretasikan, dan bertindak berdasarkan peristiwa. Ketiga situasi atau konteks saintifik yang diseleksi terutama dari kehidupan manusia sehari-hari daripada praktek dari IPA dalam suatu ruang kelas atau laboratorium [18]. Dalam pandangan lain, literasi saintifik adalah domain utama. Daerah aplikasinya adalah kesehat an, sumber daya alam, lingkungan, bahaya dan batas-batas dari IPA dan teknologi. Hal ini merupakan bidang dalam literasi saintifik yang memiliki nilai khusus untuk individu dan masya rakat dalam meningkatkan dan mempertahankan kualitas dari kehidupan [19].

\section{Hasil dan Diskusi}

\section{a. Validitas Produk Pendampingan}

Hasil pertama dari program pendampingan adalah produk dari peserta. Produk bahan ajar yang telah dihasilkan oleh 36 orang peserta dinilai. Penilaian terhadap bahan ajar didasarkan kepada kriteria dari suatu bahan ajar yang baik. Ada empat indikator penilaian terhadap bahan ajar yang digunakan, yaitu komponen isi, kompo nen penyajian, komponen kebahasaan, dan kom ponen kegrafikan. Data nilai produk bahan ajar IPA terpadu dianalisis dengan statistik deskriptif dalam bentuk tabel. Nilai minimum, nilai ratarata, dan nilai maksimum dari setiap komponen penilaian bahan ajar IPA terpadu dapat diperhati kan pada Gambar 1

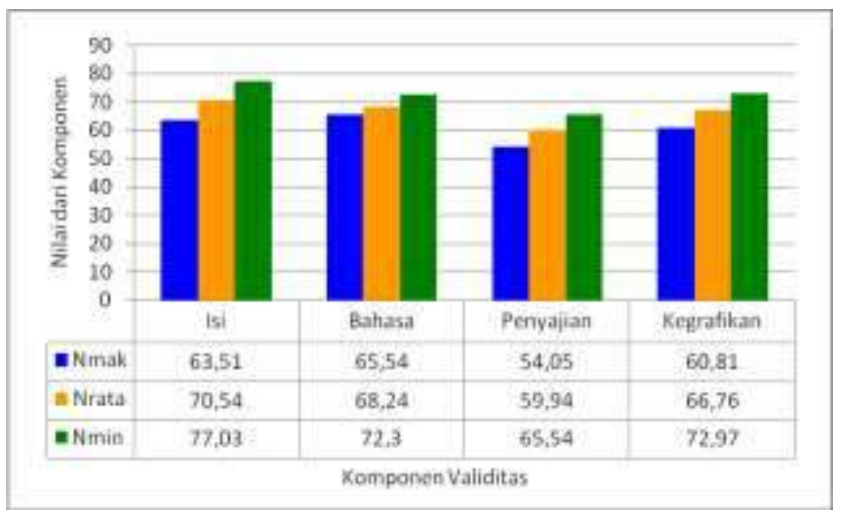

Gambar 1. Nilai Validitas Bahan Ajar IPA Terpadu

Dari analisis data pada Gambar 1 dapat dijelaskan bahwa nilai komponen isi dari bahan ajar IPA terpadu bervariasi dari 63,51 sampai 77,03 . Nilai rata-rata dari komponen isi adalah 70,54 dan nilai rata-rata ini dapat diklasifikasikan pada kategori baik. Pada komponen bahasa, nilai peserta bervariasi dari 65,54 sampai 72,30. Nilai rata-rata bahan ajar IPA terpadu pada komponen bahasa adalah 68,24 yang berada pada kategori baik. Nilai dari komponen penyajian bahan ajar IPA terpadu berada antara 54,05 sampai 59,94. Nilai rata-rata dari komponen penyajian dalam bahan ajar IPA terpadu adalah 59,95 dan nilai rata-rata ini berada pada kategori cukup. Semen tara itu, nilai dari komponen kegrafikan bahan ajar IPA terpadu berkisar antara 60,81 sampai 72,97. Nilai rata-rata dari komponen kegrafikan bahan ajar IPA terpadu adalah 66,76 dan nilai rata-rata ini dapat dimasukkan kedalam kategori baik. Nilai rata-rata validitas dari bahan ajar IPA terpadu adalah 71,96. Dengan demikian, validitas dari bahan ajar IPA terpadu dapat diklasifikasikan pada kategori baik.

\section{b. Uji coba Penggunaan Bahan Ajar}

Bahan ajar IPA terpadu yang telah dibuat dan direvisi diujicobakan kepada siswa. Ada tiga orang guru IPA yang telah melakukan uji coba penggunaan bahan ajar IPA terpadu di sekolah mereka masing-masing. Uji coba penggunaan bahan ajar IPA terpadu dilakukan pada satu kelas dari setiap SMP untuk dua kali pertemuan. Setelah uji coba penggunaan bahan ajar IPA terpadu, kepada siswa diberikan angket keprak 
tisan penggunaan bahan ajar. Ada empat kompo nen kepraktisan penggunaan bahan ajar IPA terpadu menurut siswa yang terdapat pada angket, yaitu: manfaat, mudah digunakan, kemenarikan, dan kejelasan. Hasil analisis data dari setiap indikator diperlihatkan pada Gambar 2.

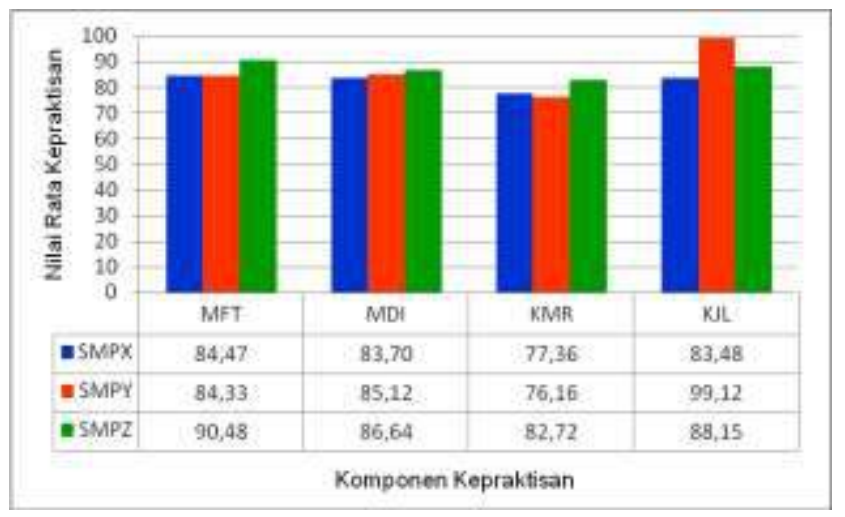

Gambar 2. Nilai Kepraktisan Penggunaan Bahan Ajar IPA Terpadu

Berdasarkan hasil analisis data Pada Gambar 2 dapat dinyatakan bahwa nilai rata-rata keprak tisan penggunaan bahan ajar IPA terpadu pada komponen manfaat menurut siswa dari ketiga SMP adalah 86,43 dan nilai rata-rata ini dapat dikelompokkan kedalam kategori baik sekali. Pada komponen mudah digunakan diperoleh nilai rata-rata kepraktisan menurut siswa adalah 85,15. Nilai rata-rata kepraktisan dalam komponen mudah digunakan termasuk kedalam baik sekali. Nilai rata-rata kepraktisan bahan ajar IPA terpadu dalam komponen kemenarikan menurut siswa adalah 78,75 dan nilai rata-rata ini dapat dike lompokkan kedalam kategori baik. Sementara itu, nilai rata-rata kepraktisan penggunaan bahan ajar dalam komponen kejelasan menurut siswa dida patkan 90,25. Nilai rata-rata dari komponen kejelasan ini berada dalam kategori baik sekali. Nilai rata-rata kepraktisan penggunaan bahan ajar IPA terpadu menurut siswa pada ketiga SMP adalah 85,14. Dengan demikian, nilai rata-rata kepraktisan penggunaan bahan ajar IPA terpadu menurut siswa untuk tiga SMP ini termasuk kedalam kategori baik sekali.

\section{c. Tanggapan Peserta Terhadap Pendampingan}

Pada akhir kegiatan program pendampingan pengembangan bahan ajar IPA terpadu, kepada peserta diberikan angket tanggapan peserta terhadap pelaksanaan kegiatan. Angket tanggapan peserta terdiri dari komponen, yaitu: 1). Pengem bangan bahan ajar (PBA), 2). pembelajaran IPA terpadu (PIT), 3). integrasi konteks dunia nyata $(\mathrm{KDN})$, 4). integrasi literasi saintifik (ILS), dan 5). penyusunan bahan ajar IPA (BAI). Nilai ratarata setiap komponen tanggapan peserta ditampil kan pada Gambar 3

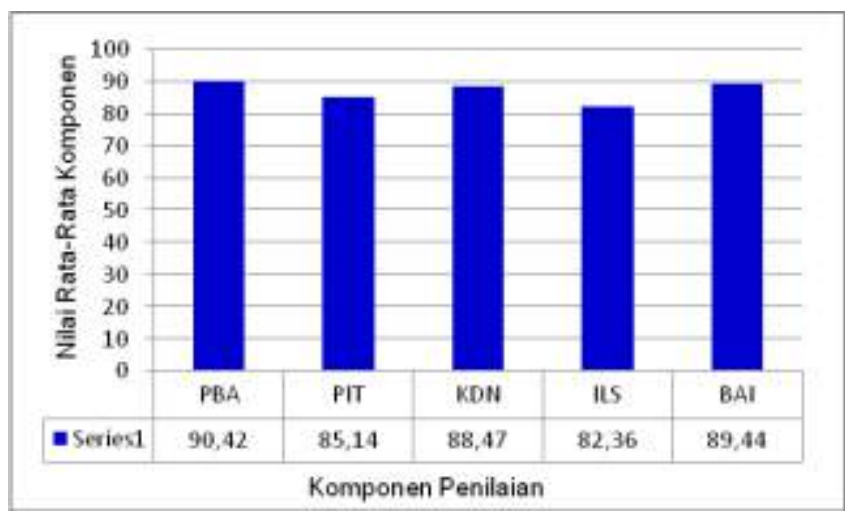

Gambar 3. Penilaian Peserta Terhadap Pelaksana an Program Pendampingan

Nilai rata-rata dari komponen tanggapan peserta terhadap pelaksanaan program pendam pingan pengembangan bahan ajar IPA terpadu bervariasi dari 82,36 sampai 90,42. Nilai rata-rata terendah adalah komponen integrasi literasi sain tifik dalam bahan ajar IPA terpadu, sedangkan nilai rata-rata tertinggi adalah nilai pengembang an bahan ajar IPA. Nilai rata-rata tanggapan peserta untuk kelima komponen adalah 87,17. Nilai rata-rata ini dapat diklasifikasikan kedalam kategori baik sekali. Hasil ini mengindikasikan bahwa umumnya peserta merasakan bahwa prog ram pendampingan pengembangan bahan ajar IPA terpadu membantu mereka dalam menguasai dan menulis bahan ajar IPA terpadu.

\section{c. Efektivitas Program Pendampingan}

Efektivitas dari kegiatan program pendamping an pengembangan bahan ajar IPA terpadu ber muatan konteks dunia nyata dan literasi saintifik ditentukan dari perbandingan antara penguasaan peserta setelah dengan sebelum kegiatan. Penguasaan peserta terhadap bahan ajar ditentu kan dari pretes sebelum kegiatan. Sementara itu, penguasaan peserta terhadap materi pengembang an bahan ajar ditentukan dari nilai postes setelah kegiatan. Hasil pretes dan postes peserta telah didapatkan selama melaksanakan kegiatan prog ram pendampingan. Data pretes dan postes dari 
peserta dianalisis dengan statistik deskriptif dan hasil analisis data ditampilkan dalam bentuk tabel. Nilai dari parameter statistik deskriptif dari data pretes dan postes ditampilkan pada Tabel 1 .

Tabel 1. Analisis Data Penguasaan Peserta

\begin{tabular}{clcc}
\hline No & Parameter Statistik & Pretes & Postes \\
\hline 1 & Nilai rata-rata & 29,09 & 73,79 \\
2 & Standar deviasi & 7,95 & 9,18 \\
3 & Variansi & 63,16 & 84,26 \\
4 & Nilai minimum & 12,50 & 51,88 \\
5 & Nilai maksimum & 43,75 & 90,00 \\
6 & Nilai p uji & 0,138 & 0,894 \\
& normalitas & \multicolumn{2}{c}{0,398} \\
7 & Nilai p uji & \multicolumn{2}{c}{0,398} \\
& homogenitas & \multicolumn{2}{c}{$-17,96$} \\
8 & Nilai t uji perban & \multicolumn{2}{c}{$-2,00$} \\
& dingan berkorelasi & Nilai t tabel & \multicolumn{2}{c}{} \\
\hline
\end{tabular}

Berdasarkan hasil analisis data pada Tabel 1 dapat dikemukakan bahwa nilai rata-rata pretes adalah 29,09 dan nilai rata-rata ini dapat diklasifikasikan kedalam kategori gagal. Disisi lain, nilai rata-rata postes adalah 73,79 dan nilai ini dapat dimasukkan kedalam kategori baik. Berarti nilai rata-rata peserta setelah mengikuti program pendampingan bahan ajar IPA terpadu lebih tinggi dari nilai rata-rata sebelum meng ikutinya. Dari uji normalitas didapatkan data dari pretes dan postes terdistribusi normal. Disisi lain, kedua data pretes dan postes mempunyai nilai varians yang sama dari hasil uji homogenitas.

Data pretes dan postes memenuhi syarat statistik parametrik untuk menganalisis data. Dengan alasan ini, untuk menganalisis perbedaan nilai rata-rata antara postes dengan pretes dapat digunakan uji perbandingan dipasangkan. Dari hasil uji perbandingan dipadangkan didapatkan nilai $\mathrm{t}=-17,96$. Nilai $\mathrm{t}$ ini berada di luar daerah penerimaan hipotesis nol. Hasil uji hipotesis ini mengindikasikan bahwa terdapat perbedaan yang berarti penguasaan peserta terhadap materi prog ram pendampingan antara setelah dan sebelum implementasi progran pendampingan bahan ajar IPA terpadu. Adanya perbedaan penguasaan peserta terhadap materi program pendampingan ini mengindikasikan adanya pengaruh yang ber arti dari program pendampingan terhadap pengua saan peserta pada taraf kepercayaan $95 \%$. Oleh karena itu, program pendampingan pengembang an bahan ajar IPA terpadu bermuatan konteks dunia nyata dan literasi saintifik adalah efektif untuk meningkatkan penguasaan peserta terhadap materi pengembangan bahan ajar.

\section{Kesimpulan}

Pada program pendampingan pengembangan bahan ajar IPA terpadu mengintegrasikan konteks dunia nyata dan literasi saintifik dapat dikemuka kan empat kesimpulan. Pertama, nilai rata-rata validitas bahan ajar IPA terpadu untuk komponen kelayakan isi, penyajian, kebahasaan, dan kegra fikan dari 32 orang peserta adalah 71,96 dan nilai ini termasuk dalam kategori baik. Kedua, nilai rata-rata kepraktisan penggunaan bahan ajar IPA terpadu pada komponen manfaat, mudah diguna kan, kemenarikan, dan kejelasan menurut siswa dari tiga SMP adalah 85,14 dan nilai ini berada dalam kategori baik sekali. Ketiga, nilai rata-rata tanggapan peserta untuk komponen pengembang an bahan ajar, pembelajaran IPA terpadu, integ rasi konteks dunia nyata, integrasi literasi saintifik dalam bahan ajar, dan penyusunan bahan ajar adalah 87,17 dan nilai dapat dimasukkan kedalam kategori baik sekali. Terakhir, program pendampingan pengembangan bahan ajar IPA terpadu mengintegrasikan konteks dunia nyata dan literasi saintifik adalah efektif untuk mening katkan penguasaan peserta terhadap materi pengembangan bahan ajar, konsep pembelajaran IPA terpadu dan integrasi literasi saintifik dalam pembelajaran IPA.

\section{Ucapan Terima Kasih}

Program pendampingan ini dapat dilaksanakan dengan baik karena adanya bantuan dari berbagai pihak. Dengan alasan ini, kami mengucapkan terima kasih kepada: 1). Rektor UNP dan Ketua LP2M yang telah memberikan hibah Program Kemitraan Masyarakat, 2). Kepala Sekolah SMP Negeri 1 Candung yang telah memberikan fasi litas tempat untuk melaksanakan program pen dampingan, 3). Ketua MGMP IPA kabupaten Agam Timur yang telah memfasilitasi pelaksa naan program pendampingan, dan 4). guru-guru IPA anggota MGMP Kabupaten Agam Timur 
yang telah terlibat secara aktif dalam kegiatan program pendampingan.

\section{Pustaka}

[1] Nichols, Jennifer Rita. 2015. 4 Essential Rules of $21^{\text {st }}$ Century Learning. Teach thought We Grow Teacher.

[2] Ogunkola, Babalola J. 2013. Scientific Literacy: Conceptual Overview, Importance and Strategies for Improvement. Journal of Educational and Social Research. Vol 3 (1)

[3] Asrizal. 2015. Studi Pendahuluan Tentang Permasalahan Kesiapan Guru Untuk Mengimplementasikan Pembelajaran IPA Terpadu Pada Siswa SMP. Jurnal Eksakta, Vol 2 Tahun XVI

[4] Sukmawati, Fatma. 2015. Pengembangan Bahan Ajar Biologi Berbasis Contextual Teaching and Learning untuk Meng efektifkan Pembelajaran Bagi Siswa SMA. Fenomena, Volume 7, No. 1

[5] Olayinka, Abdu-Raheem Bilqees. 2016. Effects of Instructional Materials on Secondary Schools Students' Academic Achievement in Social Studies in Ekiti State, Nigeria. World Journal of Education, Vol. 6, No. 1

[6] Murniati, dan Yusup. 2015. Pengembangan Bahan Ajar Mata Kuliah Laboratorium Fisika Sekolah Berdasarkan Kompetensi. Jurnal Inovasi dan Pembelajaran Fisika, Volume 2, Nomor 2

[7] Sanusi. 2015. Pengembangan Bahan Ajar Berorientasi KKNI Untuk Penguatan Scientific Approach Pada Mata Kuliah Evaluasi dan Proses Pembelajaran Matematika. Prosiding Seminar Nasional Pendidikan, FKIP Universitas Muhamma diyah Ponorogo.

[8] Margunayasa, I Gede, dkk. 2014. Pembe lajaran Terpadu Konsep dan Penerapannya. Yogyakarta: Graha Ilmu.

[9] Kurniawan, Deni. 2011. Pembelajaran Terpadu: Teori, Praktik dan Penilaian. Bandung: Pustaka Cendikia Utama.

[10] Adilah, Dina Nur dan Budiharti, Rini. 2015. Model Learning Cycle 7E Dalam Pembe lajaran IPA Terpadu. Prosiding Seminar
Nasional Fisika dan Pendidikan Fisika (SNFPF). Volume 6 Nomor 1

[11] Sugiyanto. 2010. Model-Model Pembelajar an Inovatif. Surakarta: Yuma Pustaka

[12] Suwangsih, Erna. 2008. BBM 5: Pendekatan Pembelajaran Terpadu dan Model Pembela jaran Kooperatif. Universitas Pendidikan Indonesia.

[13] Trianto. 2007. Model Pembelajaran Terpadu Dalam Teori dan Praktek. Jakarta: Prestasi Pustaka Publisher.

[14] Sears, Susan. 2002. Contextual Teaching and Learning: A Primer for Effective Instruction. United States of America: Phi Delta Kappa Education Foundation

[15] Hudson, Clemente Charles. 2011. Contextual Teaching and Learning for Practioners. Systemics, Cybernetics and Informatics. Volume 6- Number 4.

[16] Colthorpe, Kay. 2015. Progressive Develop ment of Scientific Literacy Through Assessment in Inquiry-Based Biomedical Science Curricula. International Journal of Innovation in Science and Mathematics Education, 23 (5), 52-64

[17] Hong, Ji. 2016. Science Teachers' Percep tion and Implementation of Inquiry-Based Reform Initiatives in Relation to Their Beliefs and Professional Identity. Interna tional Journal of Research Studies in Education, Vol. 5 Number 1, 3-17

[18] Utami, Budi. 2016. Scientific Literacy in Science Lesson. Prosiding ICTTE FKIP UNS, ISSN: 2502-4124 Vol 1, Nomor 1

[19] Thomson, Sue. 2013. A Teacher's Guide to PISA Scientific Literacy. Programme for International Student Assessment, Austra lian Council for Educational Research Ltd 